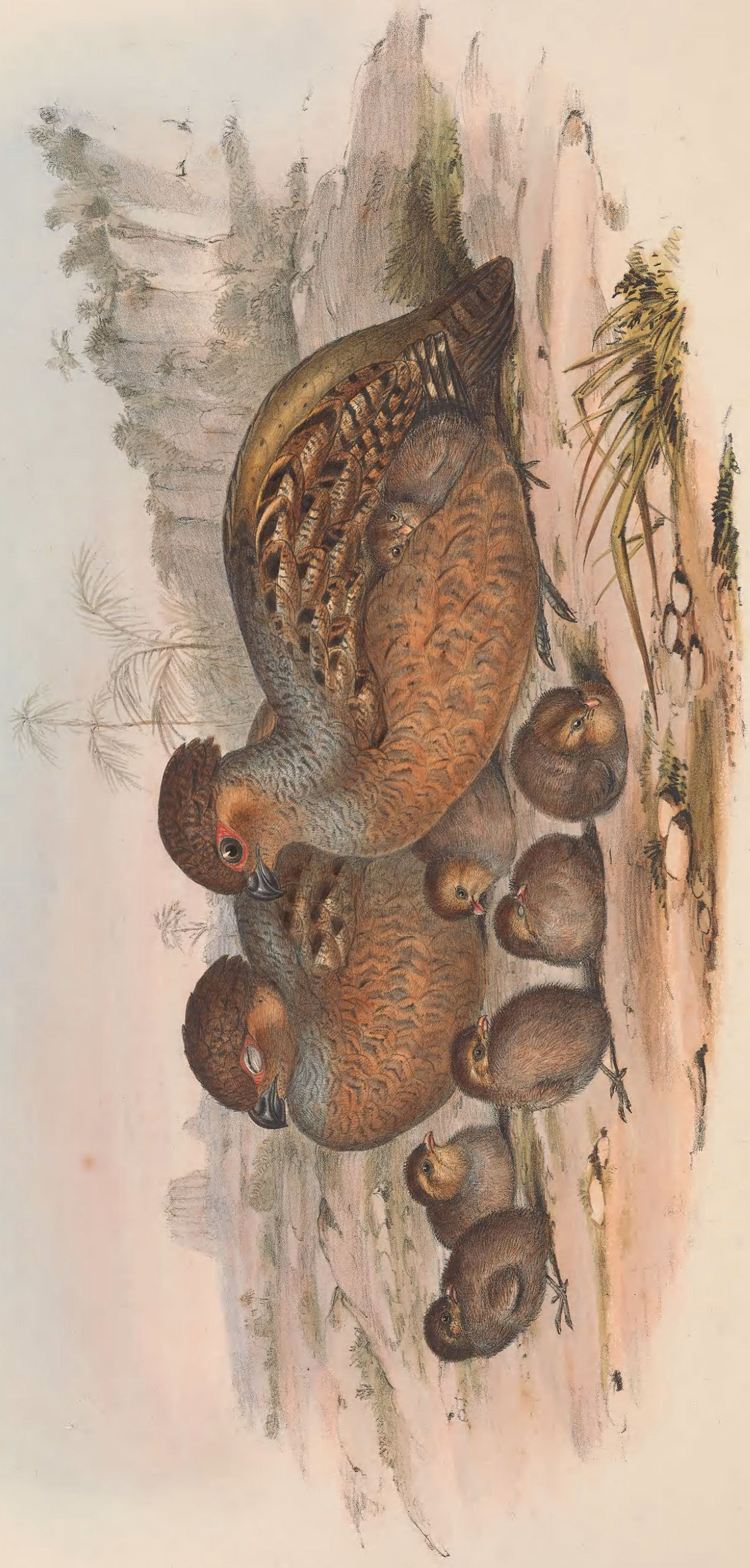

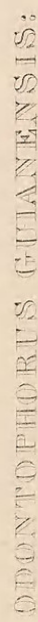




\title{
ODONTOPHORUS GUIANENSIS.
}

\section{Guiana Partridge.}

\author{
Specific Character.
}

Od. corpore subtìs, a pectore ad caudam aurantio-fusco, vel arenaceo-rubro, griseo-fusco transversim fasciato.

Head decorated with a rather full occipital crest, the feathers of which are broad and incline downwards; the general plumage is mottled brown, buff and black; cheeks, crown of the head and crest deep rusty red, crossed by indistinct bars and freckles of buff; mantle and upper part of the chest washed with grey; scapularies and tertiaries very strongly marked with deep black; primaries deep brown, crossed on the outer webs with buff; rump deep fawn-colour, minutely spotted and freckled with black; under surface from the chest downwards orange-brown or sandy red, transversely barred with greyish brown; tail very short and of a dark brown, minutely freckled with buff; bill and feet blackish brown.

Total length, 10 inches; bill, $\frac{3}{4} ;$ wing, $5_{\frac{1}{2}} ;$ tail, $2_{\frac{1}{2}} ;$ tarsi, $1 \frac{s}{4} ;$ middle toe and nail, $1_{\frac{s}{4}}$.

Tetrao Guianensis, Gmel. Syst., vol, i. p. 76\%.

Perdix Guianensis, Lath. Ind. Orn., vol. ii. p. 650.-Bonnat. and Vieill. Ency. Méth. Orn.,

Part I. p. 216.

Perdix rufina, Spix, Av. Sp. Nov., tom. ii. p. 60. pl. $76^{b}$.

Perdrix de la Guiane, Buff. Ois., tom. iv. pl. 513.

Guianc Partridge, Lath. Gen. Syn., vol. ii. p. 776.-Ib. Gen. Hist., vol. viii. p. 323.

Odontophorus rufus, Vieill. Gal. des Ois., tom. ii. p. 38. pl. 211.

Guianensis, G. R. Gray, List of Gen. of Birds, 2nd Edit. p. 80.

Tock'ro, of the Macusi, and Duraquara, of the Accawai and Arawaak Indians.

THIs species is very generally dispersed over Guiana, Cayenne and Surinam ; it is also said to inhabit Trinidad. Mr. Schomburgk informs me that it frequents the forests, and never visits the savannahs or open country; that it is usually encountered either singly or in pairs, and never in coveys; that it runs very quickly and is a shy bird; that when flushed it takes to the branches of the trees; that the eggs are deposited upon the ground; and that they are eight or ten in number and of a greenish-white colour.

It utters two distinct kinds of note; one a rather loud whistling call, which is emitted in the morning and in the evening; the other a sound like Tock'ro, whence its Macusi name. Its flesh is white, tender and delicate; it is consequently always eaten by travellers whenever it can be procured, as well as by the natives, who having their attention arrested by its call imitate it, and by this means bring the bird within range of their gun or arrows.

Mr. Waterton, when speaking of this bird in his "Wanderings," says, " before the morning's dawn you hear a noise in the forests which sounds like 'duraquara' often repeated. This is the Partridge, a little smaller and differing somewhat in colour from the English bird. It lives entirely in the forests; and probably the young brood very soon leave their parents, as you never flush more than two birds in the same place, and generally only one.

The sexes are very similar in the colour of the plumage and also in size.

Habitat, Guiana and Surinam.

The Plate represents a male, a female, and a brood of young birds of the natural size. 


\section{$2 \mathrm{BHL}$ Biodiversity Heritage Library}

Gould, John. 1850. "Guiana Partridge, Odontophorus guianensis [PI. XXIII]." A monograph of the Odontophorince, or, Partridges of America -. https://doi.org/10.5962/p.323683.

View This Item Online: https://www.biodiversitylibrary.org/item/250453

DOI: https://doi.org/10.5962/p.323683

Permalink: https://www.biodiversitylibrary.org/partpdf/323683

\section{Holding Institution}

Smithsonian Libraries

\section{Sponsored by}

Biodiversity Heritage Library

\section{Copyright \& Reuse}

Copyright Status: Public domain. The BHL considers that this work is no longer under copyright protection.

This document was created from content at the Biodiversity Heritage Library, the world's largest open access digital library for biodiversity literature and archives. Visit BHL at https://www.biodiversitylibrary.org. 